\title{
ANALISIS USAHA PEMANFAATAN JERAMI PADI (Oryza sativa) YANG DIKOSUMSI DENGAN EFEKTIF MIKROORGANISME-4 (EM-4) TERHADAP PERTUMBUHAN DOMBA SUNGEI PUTIH JANTAN
}

\author{
(Analysis of the Rice Straw Utilization (Oryza sativa) with the addition of Effective \\ microorganism 4 (EM4) on growth of Sungei Putih Lamb)
}

\author{
Johannes Sianturi, Armyn Hakim dan Zulfikar Siregar \\ Program Studi Peternakan Fakultas Pertanian Universitas Sumatera Utara
}

\begin{abstract}
The research conducted at the Faculty of Agriculture, Animal Biology Laboratory that began in September 2011 until January 2012. This study aims to determine the business value of the addition of EM4 on rice straw on sungei putih lamb. Method used is a Latin Square design 4x4. Treatments are P0 (0 ml EM4), P1 (2 ml EM4), P2 (4 ml EM4), P3 (6 ml EM4). The results showed that the average profit/loss is highest at P3 of Rp -20.603, - and the lowest at P1 Rp -7.761, -. Average Benefit Cost Ratio (B/C) is highest in the P1 at 0.984 and 0.961 for the lowest in P3. Average Break Even Point (BEP) BEP consisting of the highest production rates at P3 of Rp 31.464, and the lowest on the P1 of Rp 30.758, -. Average BEP highest production volume of 17,28 $\mathrm{kg}$ on P3 and P0 for the lowest at $16.87 \mathrm{~kg}$. Mean Income Over Feed Cost (IOFC) was highest at P1 of Rp 13.439, - and the lowest at P3 of Rp 593,-. The conclusion was that the addition of liquid Effective probiotic microorganism 4 (EM4) on rice straw given a sungei putih lamb to level $6 \mathrm{ml}$ not reduce the cost of feed and maintenance.
\end{abstract}

Keywords: Business Analysis, Liquid Probiotics EM4, Sungei Putih Lamb, Rice Straw

\begin{abstract}
ABSTRAK
Penelitian ini dilaksanakan di Laboratorium Biologi Ternak Fakultas Pertanian yang dimulai pada bulan September 2011 sampai Januari 2012. Penelitian ini bertujuan untuk mengetahui nilai usaha dari penambahan EM4 pada jerami padi terhadap domba sungei putih jantan. Metode penelitian yang digunakan dalam penelitian ini adalah metode deskriptif dengan 4 perlakuan. Perlakuannya adalah P0 (0 ml EM4), P1 (2 ml EM4), P2 (4 ml EM4), P3 (6 ml EM4). Hasil penelitian menunjukan bahwa rataan laba/rugi tertinggi adalah pada P3 sebesar Rp - 20.603,- dan terendah pada P1 sebesar Rp - 7.761,-. Rataan Benefit Cost Ratio (B/C) tertinggi adalah pada P1 sebesar 0,984 dan terendah pada P3 sebesar 0,961. Rataan Break Even Point (BEP) yang terdiri dari BEP harga produksi tertinggi pada P3 sebesar Rp 31.464,- dan terendah pada P1 sebesar Rp 30.758,-. Rataan BEP volume produksi tertinggi pada P3 sebesar 17,28 kg dan terendah pada P0 sebesar 16,87 kg. Rataan Income Over Feed Cost (IOFC) tertinggi adalah pada P1 sebesar Rp 13.439,- dan terendah pada P3 sebesar Rp 596,-. Kesimpulannya adalah penambahan probiotik cair Effektive Mikroorganisme 4 (EM4) pada jerami padi yang diberikan pada domba sungei putih jantan sampai level $6 \mathrm{ml}$ tidak dapat menekan biaya pakan dan pemeliharaan.
\end{abstract}

Kata kunci: Analisis Usaha, Probiotik cair EM4, Domba Sungei Putih Jantan, Jerami Padi

\section{PENDAHULUAN}

Ternak memberikan peran yang besar (khususnya ternak ruminansia) dalam memproduksi protein hewani yang dibutuhkan bagi peningkatan sumber daya manusia. Faktor produksi ternak yang diperlukan untuk memproduksi ternak dalam jumlah yang besar masih menjadi hambatan seperti pemenuhan kebutuhan pakan untuk ternak yang semakin besar, tidak diimbangi dengan ketersediaan bahan pakan yaitu hijauan. Ketersediaan pakan hijauan segar 
tidaklah selalu tersedia pada setiap waktu, misalnya pada musim kemarau, hijauan sulit untuk diperoleh sebab kebutuhan air oleh hijauan tidak dapat terpenuhi. Hal ini menyebabkan kesulitan bagi hijauan untuk tumbuh dan berkembang. Tentu saja hal yang demikian membuat petani peternak kesulitan dalam mendapatkan pakan hijauan untuk ternak mereka.

Upaya peningkatan ketersediaan pangan sekaligus sebagai upaya efisiensi biaya pakan dapat dilakukan dengan mencari sumber daya pakan baru yang selama ini belum dimanfaatkan oleh peternak. Indonesia sebagai negara agraris dengan lahan pertanian yang luas menghasilkan berbagai hasil samping pertanian. Menurut Badan Pusat Statistika (BPS, 2008) Provinsi Sumatera Utara, luas lahan sawah mencapai seluas 696.722 ha dengan produksi padi sebesar 3.189.758 ton. Melihat luasan tersebut akan dihasilkan jerami padi dalam jumlah 3,33 juta ton.

Jerami padi di Indonesia belum dianggap sebagai produk yang memiliki nilai ekonomis karena petani membiarkan begitu saja dan dibakar di lahannya. Di beberapa daerah, petani bahkan senang bila sawahnya bebas dari jerami. Sistem usaha tani yang intensif, jerami sering dianggap sebagai sisa tanaman yang mengganggu pengolahan tanah dan penanaman padi. Oleh karena itu, $70-80 \%$ petani membakar jerami di tempat setelah beberapa hari padi dipanen dan sebagian petani memotong jerami dan menimbunnya di pinggir petakan sawah lalu membakarnya.

Kendala utama penggunaan jerami sebagai salah satu sumber pakan ternak adalah serat kasar yang tinggi dan protein serta kecernaan (35 - 37\%) yang rendah. Agar jerami padi yang melimpah dapat digunakan pada ternak, maka perlu dilakukan suatu upaya peningkatan daya guna dari limbah tersebut.

Rendahnya kecernaan jerami ini dapat diatasi dengan penambahan feed additive. Salah satu feed additive yang dapat digunakan adalah probiotik cair EM4. Probiotik cair EM4 yang digunakan berisikan mikroba pengurai dimana di dalamnya terkandung bakteri fotosintetik (Rhodopseudomonas sp), bakteri asam laktat (Lactobacillus sp), yeast (Saccharomyces sp) dan lain-lain yang diharapkan dapat mengoptimalkan proses pencernaan yang terjadi di dalam saluran pencernaan domba.

Oleh karena itu untuk mengetahui kelayakan suatu usaha peternakan, penulis mencoba untuk melakukan analisis terhadap usaha penggemukan domba lokal jantan dengan penggunaan pakan jerami padi yang ditambahkan EM4. 


\section{BAHAN DAN METODE}

\section{Tempat dan Waktu Penelitian}

Penelitian ini dilaksanakan di Laboratorium Biologi Ternak, Program Studi Peternakan, Fakultas Pertanian, Universitas Sumatera Utara, Medan. Penelitian ini berlangsung selama 5 bulan dimulai dari bulan September 2011 sampai Januari 2012.

\section{Bahan}

Bahan yang digunakan antara lain: domba sungei putih jantan sebanyak 4 ekor dengan rataan bobot badan awal 12,79 $\pm 0,2 \mathrm{~kg}$, pakan konsentrat yang terdiri dari bungkil inti sawit, dedak padi, molasses, bungkil kelapa, tepung daun singkong, urea, mineral mix dan garam. Jerami padi sebagai pengganti pakan rumput, Effektive Mikroorgamisme 4 (EM4) untuk meningkatkan palatabilitas pakan ternak, obat-obatan seperti obat cacing (contra worm), anti bloat untuk obat kembung, rhodalon untuk desinfektan dan vitamin. Air minum diberikan secara adlibitum.

\section{Alat}

Alat yang digunakan antara lain: kandang individual 4 unit dengan ukuran 1 x $0,5 \mathrm{~m}$ beserta perlengkapannya, tempat pakan dan minum, timbangan untuk menimbang bobot hidup berkapasitas $150 \mathrm{~kg}$ dengan kepekatan 0,05 kg, timbangan berkapasitas $3 \mathrm{~kg}$ dengan kepekatan 1 gram untuk menimbang pakan, grinder untuk menghaluskan bahan pakan, alat kebersihan untuk membersihkan kandang, alat penerangan kandangan, selang atau spuit untuk menyemprotkan EM-4 ke dalam mulut domba dan alat tulis untuk menulis data.

\section{Metode Penelitian}

Metode penelitian yang digunakan adalah Rancangan Bujur Sangkar Latin (RBSL) yang terdiri dari 4 perlakuan dan 4 ulangan.

Ransum perlakuan yang diberikan adalah sebagai berikut:

P0 : Ransum dasar + 0 cc EM4

P1 : Ransum dasar + 2 cc EM4

$\mathrm{P} 2$ : Ransum dasar +4 cc EM4

P3 : Ransum dasar +6 cc Em4 


\section{Model RBSL}

Secara matematis dapat dibuat model RBSL sebagai berikut:

$Y i j k=\mu+T i+B j+K k+\sum i j k$

Dimana:

Yijk = Respon pengamatan dari perlakuan ke-i, baris ke-j dan kolom ke-k

$\mu \quad=$ Nilai tengah umum

$\mathrm{Ti} \quad=$ Pengaruh perlakuan ke-i

$\mathrm{Bj} \quad=$ Pengaruh baris ke- $\mathrm{j}$

$\mathrm{Kk} \quad=$ Pengaruh kolom ke-k

$\sum \mathrm{ijk}=$ Pengaruh galat atau sisa karena perlakuan ke-i, baris ke-j dan kolom ke-k

\section{Peubah Penelitian}

\section{Analisis Usaha}

\section{Total Biaya Produksi}

Total biaya produksi atau total pengeluaran yaitu biaya-biaya yang dikeluarkan untuk menghasilkan suatu produk, diperoleh dengan cara menghitung biaya pembelian bibit, sewa kandang dan peralatan, biaya pakan, biaya obat-obatan dan tenaga kerja.

\section{Total Hasil Produksi}

Total hasil produksi atau total penerimaan yaitu seluruh produk yang dihasilkan dalam kegiatan ekonomi diperoleh dengan cara menghitung harga jual domba dan harga jual kotorannya.

\section{Analisa Laba-Rugi}

Analisa ekonomi atau Laba-Rugi dilakukan untuk mengetahui apakah usaha tersebut menguntungkan atau rugi dengan cara menghitung selisih antara total penerimaan (total reserve) dengan total pengeluaran (total cost).

\section{Benefit Cost Ratio (B/C Ratio)}

B/C Ratio diperoleh dengan cara membagikan total hasil produksi dengan total biaya produksi atau dituliskan dengan rumus:

$$
\text { B } / \text { C Ratio }=\frac{\text { Total Hasl Produks }}{\text { Total Biaya Produks }}
$$

Dimana bila:

$\mathrm{B} / \mathrm{C}$ ratio $>1$ : efisien

$\mathrm{B} / \mathrm{C}$ ratio $=1$ : impas

$\mathrm{B} / \mathrm{C}$ ratio $<1$ : tidak efisien 


\section{Income Over Feed Cost (IOFC)}

Untuk mengetahui efisiensi penggunaan ransum secara ekonomis, selain memperhitungkan bobot badan yang dihasilkan dan efisiensi ransum, faktor efisiensi biaya juga perlu diperhitungkan. Income Over Feed Cost (IOFC) adalah suatu cara untuk mengetahui efisiensi biaya yang diperoleh dari hasil penjualan produksi dikurangi biaya ransum.

IOFC didapat dengan cara pendapatan usaha peternakan yang didapat dari berat badan ternak (bobot potong - bobot awal) dikali harga ternak per kilogramnya dikurangi dengan biaya pakan (total konsumsi dikali harga pakan).

\section{Break Even Point (BEP)}

BEP yaitu kondisi dimana suatu usaha dinyatakan tidak untung dan tidak rugi dan disebut titik impas. Analisis BEP atau titik keseimbangan adalah suatu teknik yang digunakan seorang manajer perusahaan yang mengetahui pada jumlah produksi berapa usaha yang dijalankan tidak memperoleh keuntungan atau kerugian. BEP dibagi ke dalam 2 bagian, yaitu:

a. BEP Harga Produksi yaitu diperoleh dengan cara membagikan total biaya produksi dengan bobot badan setelah pemeliharaan.

b. BEP Volume Produksi yaitu diperoleh dengan cara membagikan total biaya produksi dengan harga jual perkilogramnya.

\section{Pelaksanaan penelitian}

\section{Persiapan kandang}

Kandang dan semua peralatan dibersihkan dan dicuci, kemudian dilakukan pengapuran pada lantai dan dinding kandang sebelum proses pemeliharaan. Selanjutnya kandang dan semua peralatan disemprot dengan Rhodalon (dosis $10 \mathrm{ml} / 2,5$ liter air).

\section{Pemberian pakan dan air minum}

Pakan yang diberikan adalah konsentrat, jerami padi dan probiotik cair Effektife Mikroorganisme 4 (EM4) tanpa hijauan segar sesuai dengan perlakuan (0 ml untuk P0; $2 \mathrm{ml}$ untuk P1; $4 \mathrm{ml}$ untuk P2; dan $6 \mathrm{ml}$ untuk P3). Pemberian probiotik cair EM4 dilakukan dengan cara dicekoki ke dalam mulut domba dengan alat spuit, diberikan setelah pemberian pakan konsentrat. Pemberian pakan dan air minum dilakukan secara adlibitum. Pemberian konsentrat diberikan pada pagi hari yaitu pada pukul 07.00 wib dan probiotik cair EM4 setengah jam kemudian setelah itu diberi pakan jerami. Pemberian konsentrat kedua dilakukan pada sore hari yaitu pukul 16.00 wib dan probiotik cair EM4 setengah jam kemudian setelah itu diberikan 
jerami. Sisa pakan ditimbang pada keesokan harinya untuk mengetahui konsumsi pakan ternak tersebut. Penimbangan sisa pakan dilakukan sesaat sebelum ternak diberikan pakan kembali. Sebelum penelitian dilaksanakan, diberi waktu untuk adaptasi lingkungan dan penyesuaian terhadap perlakuan pakan selama 10 hari.

\section{Pemberian obat-obatan}

Sebelum pelaksanaan penelitian, ternak terlebih dahulu diberikan obat cacing Contra worm untuk menghilangkan parasit dalam saluran pencernaan.

\section{Penimbangan Bobot Badan}

Penimbangan bobot badan domba dilakukan setelah masa adaptasi sebagai bobot awal penelitian dan pengambilan data pertambahan bobot badan dilakukan pada setiap akhir periode selama empat periode, dimana satu periode selama 30 hari.

\section{Pengambilan data dan analisis data}

Langkah-langkah mengambil data dan analisis data:

1. Dilakukan pengukuran (pretest) yaitu data rata-rata bobot badan awal domba pada setiap level perlakuan pakan.

2. Dilakukan survei harga pakan yaitu di area pasar, poultry shop dan tempat lain yang menyangkut harga pakan dan harga peralatan-peralatan yang digunakan.

3. Dilakukan pengukuran (posttest) yaitu bobot badan awal domba dan bobot badan akhir domba, konsumsi pakan domba dan feses setiap level perlakuan.

Dilakukan analisis usaha pada data-data pretest dan posttest untuk mengetahui nilai ekonomi dari keseluruhan usaha ternak domba. Analisis usaha yang dilihat adalah analisis laba-rugi, analisis B/C ratio, analisis BEP dan analisis IOFC.

\section{HASIL DAN PEMBAHASAN}

Tabel 1 dapat dilihat bahwa perlakuan P0 mengalami kerugian rata-rata sebesar Rp 19.215,- , perlakuan P1 mengalami kerugian rata-rata sebesar Rp 7.761,- , perlakuan P2 mengalami kerugian rata-rata sebesar Rp 17.529,-, perlakuan P3 juga mengalami kerugian ratarata sebesar Rp 20.603,- . Didapat bahwa rataan kerugian terendah adalah pada P1 sebesar Rp 7.761,-. Hal ini disebabkan oleh kenaikan pertambahan bobot badan pada perlakuan P1 lebih tinggi daripada perlakuan yang lainnya. Seperti halnya pernyataan Kasmir dan Jakfar (2003), 
hasil usaha didapat dengan cara membandingkan penghasilan dan biaya selama jangka waktu tertentu. Besarnya laba atau rugi akan diketahui dari hasil perbandingan tersebut.

Tabel 1. Analisis usaha yang dilihat adalah analisis laba-rugi, analisis $\mathrm{B} / \mathrm{C}$ ratio, analisis BEP dan analisis IOFC

\begin{tabular}{cccccc}
\hline Perlakuan & $\begin{array}{c}\text { Laba/Rugi } \\
(\mathrm{Rp})\end{array}$ & $\mathrm{B} / \mathrm{C}$ & $\begin{array}{c}\text { BEP Harga } \\
\text { Produksi (Rp) }\end{array}$ & $\begin{array}{c}\text { BEP Volume } \\
\text { Produksi (kg) }\end{array}$ & $\begin{array}{c}\text { IOFC } \\
(\mathrm{Rp})\end{array}$ \\
\hline P0 & -19.215 & 0,962 & 31.450 & 16,87 & 1.983 \\
P1 & -7.761 & 0,984 & 30.758 & 17,01 & 13.439 \\
P2 & -17.529 & 0,967 & 31.290 & 17,26 & 3.671 \\
P3 & -20.603 & 0,961 & 31.464 & 17,28 & 596 \\
\hline Total & -65.108 & 3,874 & 124.962 & 68,42 & 14.762 \\
Rataan & -16.277 & 0,969 & 31.241 & 17,11 & 3.691 \\
\hline
\end{tabular}

Data pada Tabel 1 menunjukkan bahwa nilai benefit cost ratio pada perlakuan P0 sebesar 0,962, perlakuan P1 sebesar 0,984, perlakuan P2 sebesar 0,967 dan perlakuan P3 sebesar 0,961. Diketahui bahwa benefit cost ratio $(\mathrm{B} / \mathrm{C})$ tertinggi adalah pada $\mathrm{P} 1$ sebesar 0,984 . Dari hasil penelitian terlihat bahwa seluruh perlakuan memiliki nilai $\mathrm{B} / \mathrm{C}<1$ yang artinya adalah tidak efisien dijadikan suatu usaha. Hal ini sesuai dengan pernyataan Kadariah (1997) yang menyatakan bahwa untuk mengetahui tingkat efisien suatu usaha dapat digunakan parameter tingkat keuntungan dan kerugian suatu usaha yaitu dengan mengukur besarnya pemasukan dibagi besarnya pengeluaran dimana bila $\mathrm{B} / \mathrm{C}$ ratio $>1$ berarti efisien, $\mathrm{B} / \mathrm{C}$ ratio $=1$ berarti impas, dan $\mathrm{B} / \mathrm{C}$ ratio $<1$ berarti tidak efisien.

Tabel 1 menunjukkan bahwa Break Even Poin (BEP) yang terdiri dari BEP harga produksi pada perlakuan P0 sebesar Rp 31.450,-, pada perlakuan P1 sebesar Rp 30.758,-, pada perlakuan P2 sebesar Rp 31.290,- , dan pada perlakuan P3 sebesar Rp 31.464,-. Didapat bahwa rataan BEP tertinggi terdapat pada P3 sebesar Rp 31.464,- dan terendah pada P1 sebesar Rp 30.758,- dimana pada BEP harga produksi semua perlakuan mengalami kerugian karena berada diatas harga pasar sebesar Rp 30.000,-. Sebagaimana menurut Ibrahim, (2003), Break Even Point adalah titik pulang pokok, dimana total revenue $=$ total cost. Selanjutnya rataan BEP volume produksi pada perlakuan P0 sebesar 16,87 kg, pada perlakuan P1 sebesar Rp 17,01 kg, pada perlakuan P2 sebesar 17,26 kg dan pada perlakuan P3 sebesar 17,28 kg. Didapat bahwa rataan BEP volume produksi tertinggi berada pada $\mathrm{P} 3$ sebesar $17,28 \mathrm{~kg}$ dan terendah pada P0 sebesar 16,87 kg. Dari rataan BEP volume produksi menunjukan bahwa seluruh perlakuan 
berada dibawah rataan bobot hidup domba yang diperoleh pada P0 sebesar 16,1 kg, P1 sebesar $16,62 \mathrm{~kg}, \mathrm{P} 2$ sebesar 16,55 kg dan pada P3 sebesar 16,46 kg.

Dari hasil rataan IOFC dapat dilihat bahwa pada perlakuan P0 sebesar Rp 1.984,-, pada perlakuan P1 sebesar Rp 13.439, pada perlakuan P2 sebesar Rp 3.671,- dan pada perlakuan P3 sebesar Rp 596,-. Didapat bahwa rataan IOFC tertinggi terdapat pada P1 yaitu sebesar Rp 13.439,- dan terendah pada P3 yaitu sebesar Rp 596,-. Penjualan P2 mempunyai selisih lebih besar terhadap biaya pakan daripada P0, P1, dan P3, sebagaimana pernyataan dari Prawirokusumo, (1990) yang menyatakan bahwa IOFC adalah selisih antara pendapatan usaha peternakan terhadap biaya pakan. Pendapatan ini merupakan perkalian antara produksi peternakan dengan harga jual bobot hidup, sedangkan biaya pakan adalah jumlah biaya yang dikeluarkan untuk menghasilkan ternak tersebut.

Hasil penelitian diperoleh rataan penjualan per hari Pertambahan Bobot Badan (PBB) pada perlakuan P0 yaitu senilai Rp 763,-, pada perlakuan P1 yaitu senilai Rp 1.214,-, , pada perlakuan P2 senilai Rp 937,-, pada perlakuan P3 yaitu senilai Rp 913,-. Dari hasil penelitian menunjukan bahwa perlakuan P1 memberikan hasil yang terbaik. Sementara pada hasil penelitian Kukuh (2010), yang menggunakan jerami padi pada pakan dengan penambahan Em4 yang dikonsumsi pada domba diperoleh rataan hasil penjualan PBB pada perlakuan P0 (0 cc EM4) senilai Rp 1.714,-, pada perlakuan P1 (0,5 cc EM4) senilai Rp 1.894,-- pada perlakuan P2 (1 cc EM4) senilai Rp 2.038,- dan pada perlakuan P3 (1,5 cc EM4) senilai Rp 2.071,-. Dari hasil penelitian Kukuh (2010) menunjukan bahwa pemanfaatan jerami padi yang dikonsumsi dengan EM4 sebanyak 1,5cc memberikan hasil yang baik, bila dibandingkan dengan penelitian ini yang menggunakan EM4 yang melebihi dosis 1,5cc. Bila dilihat dari hasil penelitian Kukuh (2010), maka pada penelitian ini dapat disimpulkan bahwa pemakaian EM4 yang melebihi dosis 1,5 cc cenderung memberikan hasil nilai pendapatan penjualan PBB yang menurun, hal ini sejalan dengan menurunnya juga PBB yang diberi dosis melebihi 1,5 cc EM4 sehingga penggunaan optimum EM4 yang dikonsumsi pada domba sungei putih jantan adalah sebanyak 1,5 cc.

\section{KESIMPULAN}

Penambahan probiotik cair Effektive Mikroorganisme 4 (EM4) pada jerami padi yang dicekoki pada domba sungei putih jantan sampai level $6 \mathrm{ml}$ tidak menekan biaya pakan dan pemeliharaan. 


\section{DAFTAR PUSTAKA}

Badan Pusat Statistik (BPS) Provinsi Sumatera Utara,2008.

Hafied Kukuh. 2010. Pengaruh Suplementasi Probiotik Cair EM4 Terhadap Performan Domba Lokal Jantan.

Ibrahim, Y, H. M., 2003. Studi Kelayakan Bisnis, Edisi Revisi. Penerbit PT. Rineka Cipata, Jakarta.

Kadariah, 1997. Pengantar Evaluasi Proyek. Lembaga Penelitian Fakultas Ekonomi Universitas Indonesia, Jakarta.

Kasmir dan Jakfar, 2003. Studi Kelayakan Bisnis. Kencana, Bogor.

Prawirokusumo, S., 1990. Ilmu Gizi Komparatif. BPFE, Yogyakarta. 